\title{
The Causes of Cancer: An Analysis of Avoidable Risk Factors
}

\author{
A. Sangamithra \\ Professor, Department of Economics, Bharathiar University, Coimbatore, Tamil Nadu, India \\ D https://orcid.org/0000-0003-4761-8150
}

\section{OPEN ACCESS}

Manuscript ID:

ECO-2021-09023727

Volume: 9

Issue: 2

Month: March

Year: 2021

P-ISSN: 2319-961X

E-ISSN: 2582-0192

Received: 07.01.2021

Accepted: 20.02.2021

Published: 01.03.2021

Citation:

Sangamithra, A. "The Causes of Cancer: An Analysis of Avoidable Risk Factors." Shanlax International Journal of Economics, vol. 9, no. 2, 2021, pp. 37-40.

DOI: https://doi.org/10.34293/ economics.v9i2.3727

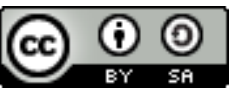

This work is licensed under a Creative Commons Attribution-ShareAlike 4.0 International License

\begin{abstract}
Recently many new causes of cancer have been recognized, such as Sunlight, tobacco, pharmaceuticals, hormones, alcohol, parasites, fungi, bacteria, salted fish, wood dust, and certain herbs. However, they are additional causes of cancer that contains beta carotene, red meat, processed meats, low intake of fiber diets, poor Exclusive Breast Feeding (EBF), obesity, increased adult height, sedentary lifestyles, etc.; there is a knowledge imbalance in knowing the causes of cancer among the physicians as well as researchers. To prevent at and permit the early detection and effective treatment is necessary in this regard. Steps were taken to prevent, control and management of cancer are disturbed by the insufficient knowledge about the disease among the population. The ultimate aim of cancer management is to reduce the prevalence of cancer and to improve the quality of life. A practical way to identify cancer control risk is to understand the real risk factors for causing cancer. When the causes are not well explained and understood, it is difficult to treat the disease. Screening of asymptomatic populations and awareness of early signs and symptoms can certainly improve the treatment of cancer. Knowing the causes of cancer and knowledge about preventing it can cure the disease, prolong our life, and improve the quality of our life. Cancer research is crucial for effective planning and strategic Cancer Control Programmes $(C C P)$.

Keywords: Factors, Cancer, Symptoms, Hormones, Pharmaceuticals, Tobacco, WOOD Dust, Quality
\end{abstract}

\section{Introduction}

Once upon a time, several publications reported that infectious agents produced only a few results that seemed irrelevant to human beings. After that, ground-breaking evidence emerged that a variety of viruses can also spread cancer in humans. There is now sufficient evidence of carcinogenicity in humans for the human T-cell lymphotropic virus, human immunodeficiency virus, hepatitis $\mathrm{B}$ virus, hepatitis $\mathrm{C}$ virus, human papilloma virus, EpsteinBarr virus, and human herpes virus. According to the International Agency for Research on Cancer (IARC). Recently many new causes of cancer have been recognized, such as Sunlight, tobacco, pharmaceuticals, hormones, alcohol, parasites, fungi, bacteria, salted fish, wood dust, and certain herbs. However, they are additional causes of cancer that contains beta carotene, red meat, processed meats, and low intake of fiber diets, poor Exclusive Breast Feeding (EBF), obesity, increased adult height, sedentary lifestyles, etc., there is a knowledge imbalance in knowing the causes of cancer among the physicians as well as researchers. To prevent at and permit the early detection and effective treatment is necessary in this regard. Steps were taken to prevent, control and management of cancer are disturbed by the insufficient knowledge about the disease among the population. The ultimate aim of cancer management is to reduce the prevalence of cancer and to improve the quality of life. A practical way to identify cancer control risk is to understand the real risk factors for causing cancer. When the causes are not well explained and understood, it is difficult to treat the disease. 
Screening of asymptomatic populations and awareness of early signs and symptoms can certainly improve the treatment of cancer. Knowing the causes of cancer and knowledge about preventing it can cure the disease, prolong our life, and improve the quality of our life. A review of discoveries of the causes of cancer is presented in this article. To predict more lives from cancer is necessary to address the real and recent causes of cancer.

\section{The Development and Causes of Cancer}

We all know that cancer begins when cells acquire the ability to grow uncontrollably and ultimately invade and damage the body's normal tissues. Cancer improvement occurs in a couple of stages, from precancerous adjustments to malignant tumors. However, no longer all cancers shape tumors, and exclusive cancers can improve at specific ranges. Sometimes most cancer cells unfold from their authentic location to different locations in the physique via the bloodstream or lymphatic system a procedure known as metastasis. It is a recognized reality that most cancers can affect many one kind components of the body, from the skin, bone, blood vessels, and muscle to the lungs, kidneys, and many different organs. Cancer can additionally affect the body's immune system, which performs a key function all through each the improvement and development of cancer. Genes are segments of DNA (Deoxyribonucleic acid) positioned on chromosomes and can mutate over time to become cancerous and result from a range of causes, along with food regimen and way of life picks as nicely as publicity to positive environmental factors. Overall, solely 5 to 10 percentages of all cancers are genetically inherited, though these are the cancers that tend to appear before in life. Today, scientists and clinicians are the usage of and creating new assessments to search for biomarkers, which can assist in deciding dangers and desirable remedy alternatives primarily based on a person patient's genetic profile.

The query of "what reasons cancer" has intrigued human beings for generations. This implied that most cancers had been brought on using exposures in the environment, alternatively than inherited genetic factors. There have been giant thinking that artificial dealers are the purpose of most cancers. Occupational and pharmaceutical retailers additionally motive cancer. An exhaustive search for viruses, herbal elements and non-viral infectious marketers, which have been a reason for most cancers, is the want of the hour. Unrestrained boom is the frequent denominator. Cancer can improve in a range of ways due to a range of specific factors. Some human beings may additionally inherit, and others we are uncovered to at some point in our lives.

Genetic elements can make contributions to the improvement of cancer. A person's genetic code tells their cells when to divide and expire. Changes in the genes can lead to misguided instructions, and most cancers can result. Genes additionally affect the cells' manufacturing of proteins, and proteins raise many of the guidelines for mobile increase and division. Some genes exchange proteins that would normally restore broken cells. This can lead to cancer. If a father or mother has these genes, they may omit the altered directions to their offspring. Some genetic adjustments occur after birth, and elements such as smoking and solar publicity can make bigger the risk. Other modifications that can result in cancer take vicinity in the chemical alerts that decide how the physique deploys or "expresses" unique genes (Medical News Today). The following are the frequent reasons for cancer.

\section{Tobacco}

Tobacco smoke has at least 70 chemical substances that motive most cancers and additionally, it is recognized as carcinogens. Every time we breathe in that smoke, these chemical substances get into our bloodstream, which consists of the chemical compounds to all components of the body. Many of these chemical substances can harm the DNA, which controls how the physique makes new cells and directs every form of telephone to do what it is made for. Damaged DNA can make cells develop differently from how they are supposed to. These uncommon cells may additionally flip into cancer. Smoking can cause cancer almost anywhere in our body such as

- Bladder

- Blood (acute myeloid leukemia)

- Cervix

- Colon and rectum

- Esophagus

- Kidney 
- Renal pelvis

- Liver

- Lungs, bronchi, and trachea

- Mouth and throat

- Pancreas

- Stomach

- Voicebox (larynx)

1. Tanning (Excessive Exposure to Ultraviolet Light): Tanning is prompted by exposure to ultraviolet (UV) radiation from the solar or tanning beds that motives genetic harm to cells on the outmost layer of the skin. The pores and skin try to stop also harm by producing melanin (the pigment that offers our pores and skin its color) that outcomes in darkening - what we name a tan. Sun and different ultraviolet (UV) mild exposures play a key position in improving pores and skin cancer. To tons of UV radiation from the sun or sunbeds can injury the genetic cloth (the DNA) in our pores and skin cells. If sufficient DNA injury builds up over time, it can motive cells to begin developing out of control, which can lead to pores and skin cancer. Anyone can boost pores and skin cancer. However, some human beings can have a greater risk.

2. Diet: A few dietary outcomes on most cancer hazards have been set up through many researchers. Avoiding overweight/obesity, limiting alcohol consumption and growing bodily recreation will minimize most cancers risk, limiting consumption of Chinese-style salted fish and minimizing dietary publicity to aflatoxin in populations the place these dietary elements are important. By limiting the consumption of preserved and purple meat, salt-preserved ingredients, food and salt, and very warm drinks and meals, the danger of most cancers can be reduced. If different dietary elements are hooked up to affect most cancers danger, then these can be brought to present coverage frameworks.

3. Alcohol: Alcohol consumption has been linked to an elevated hazard for a range of sorts of cancer. Alcohol most strongly improved the dangers for cancers of the oral cavity, pharynx, esophagus, and larynx. Concurrent tobacco use, which is frequent amongst drinkers, enhances alcohol's outcomes on the hazard for cancers of the higher digestive and respiratory tract. Earlier lookup confirms that high-level alcohol consumption (i.e., greater than 4 drinks per day) consequences in an enormous hazard of most cancers development. Lower stages of consumption result in a relatively accelerated danger for a range of cancers.

4. Unsafe sex (leading to viral infection)

5. Inflammatory conditions, such as ulcerative colitis or obesity

6. Chemical carcinogen exposure

7. High-dose chemotherapy and radiation (mainly in children being treated for existing cancers)

8. Hormonal drugs

9. Immune-suppressing drugs (taken by transplant recipients)

10. Radioactive materials

In addition to different elements related to growing older and senescence, older men and women are greater likely to have had publicity to environmental chance elements and are consequently recognized with most cancers lots greater often than younger people. When it comes to youngsters with cancer, new immunotherapy strategies are imparting for the opportunity of treating them no longer solely extra effectively, however additionally except some of the detrimental facet results that can accompany traditional treatments. Although there are many factors at play in the improvement of cancer, the remedies at our disposal are continuously enhancing and adapting as new lookup affords perception into quite several chance elements (Cancer Research Institute).

Table 1: Risk Factors of Cancer Pervasiveness

\begin{tabular}{|l|l|}
\hline \multicolumn{1}{|c|}{ Main Risk Factors } & Co-morbidity Conditions \\
\hline Use of Tobacco & $\begin{array}{l}\text { 1. Greater risk of } \\
\text { cardiovascular disease } \\
\text { 2. Chronic respiratory } \\
\text { disease }\end{array}$ \\
\hline $\begin{array}{l}\text { HBV and HCV } \\
\text { (Hepatitis B Virus, } \\
\text { Hepatitis C Virus ) }\end{array}$ & $\begin{array}{l}\text { Significant burden from } \\
\text { other significant liver } \\
\text { diseases }\end{array}$ \\
\hline $\begin{array}{l}\text { HPV (Human Papilloma } \\
\text { Virus) }\end{array}$ & $\begin{array}{l}\text { Small burden from other } \\
\text { conditions }\end{array}$ \\
\hline $\begin{array}{l}\text { H. pylori (H. pylori is a } \\
\text { common type of bacteria } \\
\text { that grows in the digestive } \\
\text { tract and has a tendency to } \\
\text { attack the stomach lining) }\end{array}$ & $\begin{array}{l}\text { Duodenal and gastric } \\
\text { ulcers can also be related } \\
\text { with H pylori gastritis in } \\
\text { adults and it is unique in } \\
\text { children. }\end{array}$ \\
\hline
\end{tabular}




\begin{tabular}{|l|l|}
\hline $\begin{array}{l}\text { Minimum intake of } \\
\text { vegetables and fruits }\end{array}$ & $\begin{array}{l}\text { The Maximum burden of } \\
\text { cardiovascular disease }\end{array}$ \\
\hline Alcohol Consumption & $\begin{array}{l}\text { The burden of injuries, } \\
\text { neuropsychiatric } \\
\text { conditions, cardiovascular } \\
\text { conditions, and other } \\
\text { causes }\end{array}$ \\
\hline Sedentary lifestyle & $\begin{array}{l}\text { Greater risk of } \\
\text { cardiovascular and other } \\
\text { Non-Communicable } \\
\text { Diseases (NCD) }\end{array}$ \\
\hline Obesity & $\begin{array}{l}\text { Greater risk of } \\
\text { cardiovascular and other } \\
\text { Non-Communicable } \\
\text { Diseases (NCD) }\end{array}$ \\
\hline Exposure of air pollution & $\begin{array}{l}\text { Risk of incurable } \\
\text { respiratory disease }\end{array}$ \\
\hline
\end{tabular}

\section{Conclusion}

A realistic way to perceive most cancers' manipulate hazard is to think about what we recognize about the reasons and dangerous elements for frequent cancers, and then reflect on consideration on how to put off or regulate them in methods that would forestall and decrease most cancers prevalence. When the reasons are now not nicely defined and understood, it is challenging for human beings to get cured of most cancers or to care for those with most cancers who can't be cured. It is a frequent reality that early detection, which includes a screening of asymptomatic populations and consciousness of early symptoms and symptoms, can amplify the prevalence of most cancer cure. Knowing the motives of most cancers and information about stopping them can remedy the disease, extend our life, and enhance the exceptional of our life. In addition to that, surveillance and lookup are imperative for each superb planning and strategic Cancer Control Programmes (CCP).

\section{References}

Alwan, A, et al. Assessment of National Capacity for Non-communicable Disease Prevention and Control, World Health Organization, 2001.
Baker, Stuart G. "A Cancer Theory Kerfuffle can Lead to New Lines of Research." Journal of the National Cancer Institute, vol. 107, 2014.

Barton, Michael B, et al. "Role of Radiotherapy in Cancer Control in Low-Income and MiddleIncome Countries." The Lancet Oncology, vol. 7, 2006, pp. 584-595.

Blackadar, Clarke Brian. "Historical Review of the Causes of Cancer." World Journal of Clinical Oncology, vol. 7, 2016, pp. 54-86.

Bruce, Nigel, et al. "Indoor Air Pollution." Disease Control Priorities in Developing Countries, edited by Dean $\mathrm{T}$ Jamison, et al., Oxford University Press, 2006.

Darby, S, et al. "Radon: A Likely Carcinogen at all Exposures." Annals of Oncology, vol. 12, 2001, pp. 1341-1351.

Darby, S, et al. "Radon in Homes and Risk of Lung Cancer: Collaborative Analysis of Individual Data from 13 European Case-Control Studies." BMJ, vol. 330, 2005.

Food, Nutrition, and the Prevention of Cancer: A Global Perspective. World Cancer Research Fund, American Institute for Cancer Research, 1997.

Mack, S., et al. "Epigenomic Alterations define Lethal CIMP-Positive Ependymomas of Infancy." Nature, 2014, pp. 445-450.

Meenakshi, R., and R Naagarajan. "An Econometric Analysis of Health Status of Women Cancer Patients in Coimbatore District." Shanlax International Journal of Economics, vol. 6, no. 2, 2018, pp. 210-223.

Vaux, David L. "In Defense of the Somatic Mutation Theory of Cancer." Bioessays, vol. 33, 2011, pp. 341-343.

Versteeg, Rogier. "Cancer: Tumours Outside the Mutation Box.” Nature, 2014, pp. 438-439.

Vogelstein, Bert, and Kenneth W. Kinzler. "The Path to Cancer - Three Strikes and You're Out." The New England Journal of Medicine, vol. 373, 2015, pp. 1895-1898.

"What are the Causes of Cancer?" Cancer Research Institute, 2019.

\section{Author Details}

Dr. A. Sangamithra, Professor, Department of Economics, Bharathiar University, Coimbatore, Tamil Nadu, India, Email ID: a.sangamithra@gmail.com 